\title{
Patch Dosing Unit
}

National Cancer Institute

\section{Source}

National Cancer Institute. Patch Dosing Unit. NCI Thesaurus. Code C48524.

A dosing unit equal to the amount of active ing redient(s) contained in a patch. 